\title{
WEBSITE DEVELOPMENT OF HARVEST PRODUCTS BY "TIDAK MENGELUH, BERDOA DAN BEKERJA COMMUNITY"
}

\author{
Ina Melati INDARTOYO ${ }^{1 *}$, Ahmad Maulin NAUFA², Devi Kurniawati HOMAN", \\ and Aliya Mutiara DEVI ${ }^{4}$ \\ ${ }^{1}$ Global Business Marketing Program, BINUS Business School, BINUS University \\ ${ }^{2}$ Management Program, BINUS Business School, BINUS University \\ ${ }^{3}$ Animation Program, School of Design, BINUS University \\ ${ }^{4}$ Global Business Marketing Program, BINUS Business School, BINUS University \\ *imelati@binus.edu
}

\begin{abstract}
There are many ways that community groups do to survive during the pandemic caused by the COVID-19 virus. One way to survive is done by one of the community groups to work together by planting vegetables that can be consumed as daily food ingredients that are filling and nutritious. Over time, the community realized that its strategy to survive could also be materially profitable. Self-harvested vegetable products can be developed into commercial products with a marketing strategy that combines websites and merchandise strategies. One of the main problems faced by the community is that the community has not adequately understood the strategy for managing and developing a website. However, the community already knows the usefulness of the website and how website development can benefit the community, not only in terms of selling vegetables but also community awareness that is easier to build. Furthermore, with public awareness, more parties will know the products produced by the community. Public awareness will also positively impact the sustainability of the business ecosystem in the community. The existence of synergies, the right strategy in managing and developing websites, collaboration with the community, and community awareness will have a good impact, especially for the community, not only in growing businesses to survive but also in being an example for others communities.
\end{abstract}

Keywords: Website Development, Commercialization, Community Service and Integrated Marketing Communication.

\section{BACKGROUND}

Data from the Central Statistics Agency (BPS) published a report of the results of the socio-demographic survey of the impact of COVID-19 on Monday (1/6/2020) (banten.idntimes.com, 2020). The presentation of the results of this survey aims to provide information to stakeholders to formulate policies in dealing with this pandemic. The report states that the community groups most affected during the COVID-19 pandemic are: poor people, vulnerable to poverty, and informal workers. It is known, as many as 70.53 percent of respondents in the low-income group (less than Rp. 1.8 million) admitted to experiencing a decrease in income. Meanwhile, 46.77 percent of the people with an income of Rp. 1.8 million to Rp. 3 million also suffered the same fate. Around 37.19 percent of the community group with an income of Rp. 3 million to Rp. 4.8 million and 31.67 percent of the group with an income of Rp. 4.8 million to Rp. 7.2 million said their income had decreased. The income of these informal workers decreases and disappears with the enactment of the PSBB (banten.idntimes.com, 2020). The data seems to represent most of the regions in Indonesia, including in the Tangerang area. According to the Central Statistics Agency (BPS) data, the number of unemployed in Tangerang City has reached 97,344 for the August 2020 period. This number has increased from the February 2020 period, which gained 79,041 (banten.idntimes.com, 2020).

However, the people in the two areas continue to strive for the welfare of their family life through various means. One way to do this is to use the remaining land in their respective rented houses to grow vegetables used daily, such as kale, lettuce, shallots, and green onions (figure 1.1). During months of farming, people can produce vegetables that they can consume and share with neighbors. Interviews and observations resulted in the finding that the vegetable products made where fresh vegetables and free of harmful pesticides. Communities in these areas have their group strengths from informal work. Some of them are online motorcycle taxi drivers, thus enabling the development of potential distribution channels. From the social aspect, the people in this area have pretty close social relations with each other. During this pandemic, community groups in the area formed a community to support each other's lives. The harvests produced independently by the community are as follows:

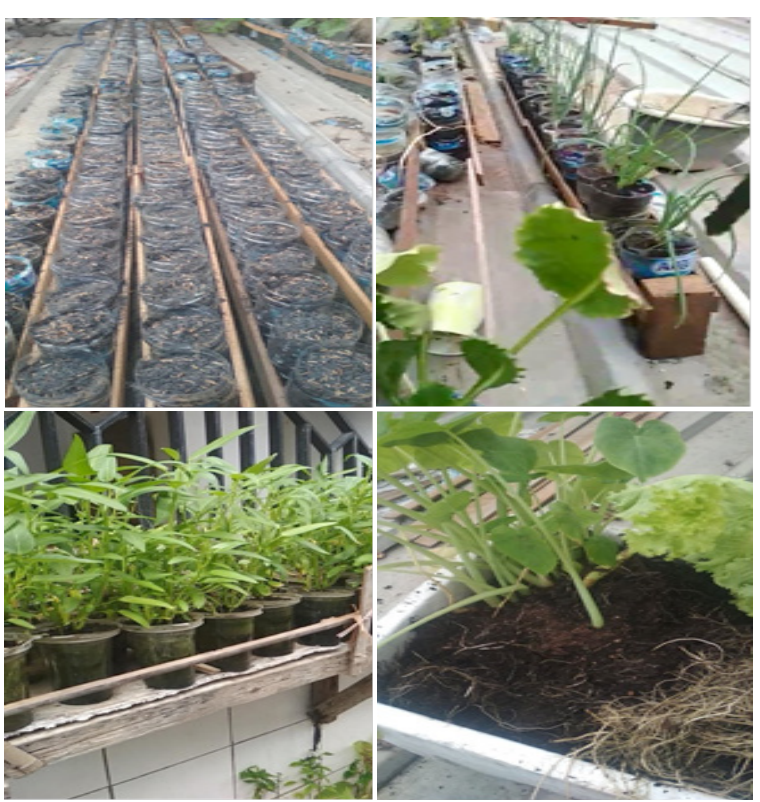

Figure 1. Organic Vegetable Products at Planting Period 
In particular, the community wants to manage their crops and the two strengths they have to achieve a better life, especially the desire to continue to provide the best education for their children and survive independently. On this basis, interviews and further observations were carried out to find out the possibility of realizing the wishes of the communities.

- Show partner profiles that are equipped with data and pictures/photos of partner situations.

- Explain the potential and business opportunities of partners.

- Describe and classify in terms of production and business management.

- Disclose all resource condition issues faced by partners

\section{METHOD}

Based on interviews and initial observations, 2 (two) findings of the main problems faced by the community in carrying out the Commercialization of their vegetable products were made, namely:

1. There is no clear company orientation, so the community cannot determine the value of the products they sell. Based on interviews and observations, The community should focus on matters related to unique distribution channels and promotional programs in the form of bundling/packages

2. The community does not yet have plans to promote online media.

3. The advent of the Internet provided the stimulus for a substantial change in the communication landscape. In its early stages, the Internet was considered and handled as a publishing platform that enables companies to disseminate information to the broader public. Currently, consumers can only search for information and read it, so content contributions are made available to companies, and interactions are limited (Kaplan \& Haenlein, 2010; O'Reilly, 2007). The emergence of social media has added a new and unique communication dimension to one-way communication, which is now turning into multi-way contact. As a result, the focus is shifting "from enterprise to consumer, individual to the community, node to the network, publishing to participation, and intrusion to the invitation (Berthon et al., 2012). Companies can use social media to interact with their customers and be used by customers to interact with the company and other customers (Mangold \& Faulds, 2009).

4. Direct marketing tactics allow businesses to communicate directly with customers through various media, including electronic bulletins, mobile messaging applications, websites, online advertisements, flyers, online and offline catalogs, promotional letters, targeted television advertising, newspapers and magazines, and outdoor advertising. Direct marketing often relies on propositions, offers, communications, channel choices, and target customers. Although advertising consists of non-personal communication, direct marketing seeks to create a one-to-one personal relationship with customers to generate a response. The idea that value arises for the customer in the form of value shifts the emphasis from a message-driven, instrument-based view of communication to a customer-oriented focus. The customer perceives value in the message and communication process. Instead of focusing on the available instruments or the outcome of messages from only one particular sender as, in a typical communication campaign, the focus turns to customer value creation, and towards how, and based on what messages, communication value, emerges for the customer (Mick \& Buhl, 1992).

5. The Internet and websites have grown over the last decade to become increasingly important as a marketing communication tool in today's rapidly changing business environment. Apart from that, it is also an essential source of income. The presence of companies on the Internet is now a necessity. A company on the Internet could increase a company's sales and marketing efforts. It can also broaden a company's circle of influence by providing other ways to communicate it to its clients, prospects, and the public. The power of realtime interactions with prospects and customers doesn't just create new ways to communicate.

This community service is carried out with 2 (two) main concepts. First, collaborate directly with the community to find out the community's core problems, desires, and characteristics. Second, the implementation of the promotion strategy is based on the core problems that occur in the field, the wishes of the community regarding problem-solving and community characteristics.

The collaboration that occurs dramatically facilitates the creation of website promotions. Furthermore, the partnership provides easy access to hydroponic gardens owned by the community. In addition, further cooperation also facilitates communication between the two parties, which significantly improves website promotional content.

\section{RESULTS AND DISCUSSION}

This community service program offers 4 (four) solutions to solve all existing problems. Several stages of the solution that will be carried out in this research are as follows:

1. Prepare products to be commercialized, including:

a. Collecting used mineral bottles from both the household and non-household sectors. Used mineral bottles needed to be ranged from 10002000 bottles. The use of used bottles, in this case, provides benefits not only for the community but also for the environment. For the community, used bottles can be purchased at a meager price so that it is not too burdensome for the community in terms of capital financing. In addition, the use of used 
bottles will make the surrounding environment more sustainable because the use of used bottles will reduce plastic waste.

b. Turning used mineral bottles into plant pots by cutting them into 2 (two) parts. One used bottle can become 2 (two) planting media to plant and harvest more vegetables.

c. Planting vegetables on house tiles by implementing the following suggestions:

i. So that plants get enough sunlight and water, especially from rainwater. However, even without rainwater, water sources can still be managed by using a portable water machine.

ii.Punch a few holes in the bottle to allow more roots to come out.

iii. Using rice water and soaking overnight to provide more nutrients to the plant.

d. Harvesting will take place approximately on the twenty-first day.

e. After harvesting, vegetables are packaged to be sent to consumers

f. The profit from the sale will be used as capital to buy fertilizer and seeds and used mineral bottles for the replanting process.

2. Create marketing strategies which focus on products, brands, and distribution channels. The implementation of the marketing strategy also focuses on developing commercial websites and making merchandise. The marketing strategy was first carried out by conducting market research to find out the choices of potential consumers for product brands produced by the community. Market research was conducted by distributing questionnaires to 122 respondents. The questionnaire contains questions related to the product community. The data obtained through questionnaires were then processed using the primary method, namely finding the most answers. Based on data processing results, it is known that several important things are useful as the basis for developing commercial websites and making merchandise. The results of data processing are as follows:

1. The brands that potential consumers choose are; Sayur Mayur Kebunku. This brand also becomes the commercial website address that the community can use to sell their harvested products in online media. The registered commercial website is http://sayurmayurkebunku.com/. Website content consists of 4 (four) main parts, namely;

a. Company section: this section, however, tells everything about Sayur Mayur Kebunku related to Sayur Mayur Kebunku as a business organization or things that are not related to Sayur Mayur Kebunku as a business organization related to the products sold by Sayur Mayur Kebunku. b. Promotion section: this section describes the unique selling prepositions and promotions offered by Sayur Mayur Kebunku (figure 2).

c. Purchase and payment procedures section describe the ordering mechanism and payment methods consumers can make in purchasing Sayur Mayur Kebunku products (figure 2).

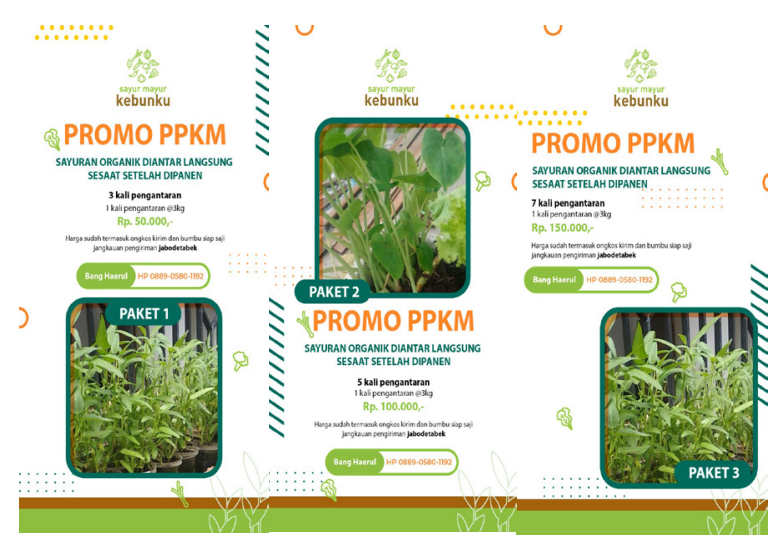

2. The logo that is the choice of prospective consumers is represented in the following figure 3;

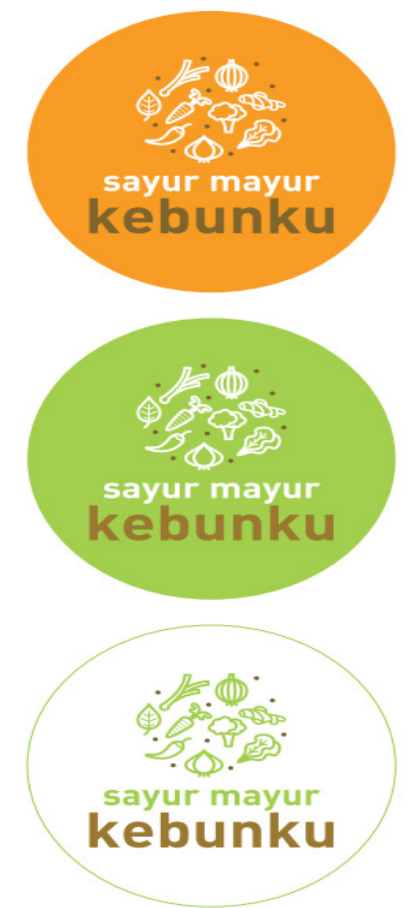

Figure 3 Prospective Consumers' Choice Logo

3. The promotional program that Sayur Mayur Kebunku offer is one of the unique selling points of the Sayur Mayur Kebunku brand because this promotional program offers product bundling packages and an introduction to its services. Sayur Mayur Kebunku offers 3 (three) packages that consumers can choose from and purchase in this promotional program. These packages provide 3, 5, and 7 times vegetable delivery services in 1 (one) package purchase. Thus, consumers will get 3 (three) $\mathrm{kg}$ of vegetables and free shipping services within the Jabotabek area for every delivery (figure 2). 
The delivery of vegetables will be carried out precisely at the harvest time that will cause delivery time not always on time. Therefore, consumers will be given information on the planting schedule and the time tolerance before making a payment. Initial information is important to avoid consumers' disappointment due to delays in delivery due to planting and harvesting times which may be hampered by weather or other complicated things for the community to control. One of the pieces of merchandise made by the community is recycled packaging from used newspaper materials as vegetable wrappers that will be delivered to consumers and a sticker with the Sayur Mayur Kebunku logo as a community identity. Besides being an identity, merchandise is also expected to raise awareness of other potential consumers on Sayur Mayur Kebunku (figure 2).

4. social media in the form of Instagram was also successfully created to build awareness of the vegetable brand in my garden and what vegetable products are approaching harvest time at that time. In addition, social media is also helpful as a distribution channel for related information that is ongoing during that period. Instagram social media accounts that have been successfully created are: sayurmayurkebunku.

\section{CONCLUSION}

Two things have become quite big obstacles in the development of this website. First, problems related to vegetable products, which are often not harvested properly due to the weather. Weather uncertainty that affects the harvesting vegetable process makes it difficult for the community to determine which vegetables to sell. So it is also difficult for the community to fill out promotional content on social media and websites.

Second, one of the things that makes a website attractive is the visual aspect. Unfortunately, due to the tightened social regulations imposed by the Government, it is difficult to carry out product shooting activities for visual materials on websites.

\section{ACKNOWLEDGEMENT}

"This community service activities are supported by Community Development Office, Bina Nusantara University as a part of Bina Nusantara University's Internal Research Grant entitled, PENGEMBANGAN WEBSITE UNTUK KOMERSIALISASI PRODUK HASIL PANEN MANDIRI KOMUNITAS TIDAK MENGELUH, BERDOA DAN BEKERJA, with contract number: No. 024/VR.SACD/IV/2021 and contract date: 23 April 2021."

"This community service was carried out due to good cooperation between the community and the academician team of BINA NUSANTARA University, including our teammate who has passed away, Ahmad Maulin Nauva. Rest in peace, your duty has been completed well."

\section{REFERENCES}

Berthon, P.R., Pitt, L.F., Plangger, K. and Shapiro, D. (2012), "Marketing meets Web 2.0, social media, and creative consumers: implications for international marketing strategy", Business Horizons, Vol. 55 No. 3, pp. 261-271.

Kaplan, A.M. and Haenlein, M. (2010), "Users of the world, unite! the challenges and opportunities of Social Media”, Business Horizons, Vol. 53 No. 1, pp. 59-68.

Mangold, W.G. and Faulds, D.J. (2009), "Social media: the new hybrid element of the promotion mix," Business Horizons, Vol. 52 No. 4, pp. 357-365.

Mick, D. and Buhl, C. (1992), “A meaning-based model of advertising experiences", Journal of Consumer Research, Vol. 19 No. 3, pp. 317-338.

O'Reilly, T. (2007), “What is Web 2.0: design patterns and business models for the next generation of software", International Journal of Digital Economics No. 65, pp. 17-37.

https://banten.idntimes.com/news/banten/muhammadiqbal-15/97344-orang-di-kota-tangerang-berstatuspengangguran/1 